Dijana Lukić Univerza v Ljubljani Filozofska fakulteta

Slovenija

dijana.lukic@gmail.com
DOI: https://doi.org/10.18485/slovenika.2017.3.1.2

UDK: 314.15-026.48(=163.6)(497.113)"19"

Originalen znanstveni članek

\title{
»Drugega skoraj ne ostaja, ko zapustiti milo domovino in si drugje domovja iskati« ali kratek pregled migracijskih tokov Slovencev v Vojvodino
}

Povzetek

Migracije so bile in vedno bodo neizogiben del osebnih in kolektivnih življenj. $\checkmark$ naravi ljudi je, da migrirajo, pa naj si bo to del zavednega ali nezavednega procesa, posledica načrtovanih ali nenačrtovanih politik, socio-ekonomskega razvoja ali drugih lastnosti okolja, ali pa preprosto rezultat nekih osebnih potreb in želja posameznika. Vojvodina je bila od nekdaj privlačen prostor za naseljevanje in prepletanje različnih etničnih skupin in del te demografske pestrosti, ki se danes kaže $v$ obliki večpripadnosti in transnacionalni identifikaciji, so (bili) tudi Slovenci. Pričujoči prispevek je del obsežnejše zgodovinsko-etnološke obravnave Slovencev v Vojvodini, ki je nastala na podlagi terenskega dela avtorice v Novem Sadu od oktobra 2007 do februarja 2008 in je v celoti objavljena v diplomskem delu »Slovenci v Vojvodini: društvo Slovencev »Kredarica« $\checkmark$ Novem Sadu« (Oddelek za etnologijo in kulturno antropologijo Filozofske fakultete Univerze v Ljubljani, 2009). Avtorica v prispevku prikaže zgodovino naseljevanja Slovencev v Vojvodino od konca 19. stoletja do leta 1981, s posebnim poudarkom na dveh vzajemnih procesih, agrarni reformi in kolonizaciji, ki sta zaslužni za slovenski delež med vojvodinskim prebivalstvom, pri čemer posebej izpostavlja drobce etnoloških pričevanj iz osebnih zgodb ljudi, ki razkrivajo vzgibe in vzroke za izseljevanje iz domovine.

Ključne besede: migracije, izseljenci, kolonizacija, agrarna reforma, Slovenci v Vojvodini 


\section{Vojvodina kot predmet načrtnih naseljevanj}

Vojvodina je bila od nekdaj privlačna pokrajina za bivanje. Posredni in neposredni vplivi geografskih lastnostih okolja, kot so plodne humusne ravnice in velika polja pašnikov, so pogojevali življenje in vplivali na pojav »metanastazičnih premikanj in tokov«, kot jih imenuje Cvijić. Govorimo o stoletnih premikanjih izseljencev iz matičnih ozemelj na območje Vojvodine in njenih treh pokrajin: v Srem, Bačko in Banat (Cvijić 1987).

Posamezna zgodovinska obdobja so pogojevala različne oblike preseljevanj $v$ Vojvodino, tako $v 14$. in 15 . stoletju zasledimo načrtno kolonizacijo, ki mu je po vojni z Osmani v 16. stoletju sledilo demografsko opustošenje teh krajev, da bi se nato zgodilo naseljevanje plemstva iz Nemčije in severa Ogrske (Domonji 2000, 18) ter naselitev 40.000 srbskih družin v Bački in Banatu za čas velike selitve Srbov leta 1690 pod vodstvom patriarha Arsenija Čarnojevića (Iskruljev 1925, 9).

Množično naseljevanje je bil tudi načrt nekdanjega avstrijskega cesarstva, nato Madžarske, o varovanju južnih predelov, ki so mejili z osmanskim cesarstvom (pozneje Srbijo) ter omejevanju političnega in ekonomskega vpliva Srbov, kar so dosegali z naseljevanjem pripadnikov različnih etničnih skupin, pri katerih nacionalna komponenta ni bila dokončno izražena (Bukurov 1957).

Številnejše je bilo naseljevanje kolonistov iz nemških oblasti po Bački in Banatu od leta 1720 do 1762. Leta 1790 so bili tudi v Sremu. Slovaški živelj, ki je prišel iz Karpatov okoli leta 1740, je naselil Bačko, pozneje Banat in Srem. Madžarske plemiče in koloniste so naselili na zemljo, ki so jo predhodno odtujili srbskim staroselcem, predvsem $\checkmark$ Bački, pozneje pa so se številni preselili $\vee$ Banat. Rusine na bačkih posestih najdemo od konca štiridesetih let 18. stoletja pa vse do leta 1765 , ko so prešli v Srem. V drugi polovici 18. stoletja so se tam naseljevali tudi Romuni, ki so se predhodno samoiniciativno preseljevali iz Karpatov v Banat, od omenjenega obdobja pa načrtno. Srbi in Hrvati so prihajali iz Srbije, Bosne, Like in Dalmatinske Zagore (Iskruljev 1925; Domonji 2000).

V 18. in 19. stoletju so avstrijske in ogrske oblasti v Vojvodino naselile Nemce, Madžare, Slovake, Čehe, in naj ne čudi podatek, celo Francoze in Špance (Filipović 1958, 8-10).

Po koncu madžarske uprave je $v$ Vojvodini prišlo do sprememb, med katerimi je bila največja začetek izvajanja agrarne reforme in kolonizacije v letih od 1918 do 1941. Slednja se je odvijala predvsem iz etnopolitičnih razlogov, saj so bile $v$ Vojvodini $\vee$ skupnem seštevku druge narodnosti številnejše kot pa srbska (Filipović 1958, 8-10).

Leta 1918, ko je nastala Kraljevina Srbov, Hrvatov in Slovencev, je bila v njen teritorialni okvir vključena tudi Vojvodina, ki so jo tedaj sestavljali Banat, Bačka in Baranja (Gaćeša 1995, 479). Državni popis prebivalstva, $v$ katerem se je $v$ etničnem pogledu spraševalo po veroiz-

$$
36
$$




\section{Lukić}

»Drugega skoraj ne ostaja, ko ...

povedi in maternem jeziku, in ne po narodnosti, 31. januarja leta 1921 navaja, da je Vojvodino naseljevalo 1.367 .320 prebivalcev, 81 prebivalcev na kvadratni kilometer, kar jo je po naseljenosti uvrščalo na prvo mesto med območji v Kraljevini Jugoslaviji (Popović 1925, 68; Kržišnik - Bukić 1992, 175).

Po prvi svetovni vojni so se številni Madžari in Romuni izselili in odšli nazaj v svoje matične države, Nemci v Ameriko. Različne vrste kolonizacije so pripeljale številne priseljence iz sosednjih območij in držav (Filipović 1958). Največ je bilo srbskih vojnih prostovoljcev in invalidov iz Like, Srbije, Črne gore, Bosne in Hercegovine ter Makedonije (Domonji 2000, 19).

Da kolonizacija ni imela samo nacionalno-politično usmeritev, dokazujejo ekonomski vzroki naseljevanja revnih borcev iz zaostalih predelov, dinarskih krajev, Južnega Pomoravja, Makedonije in Slovenije (Filipović 1958, 8-10).

Dogodki druge svetovne vojne so pripeljali do izselitve Nemcev, ki so se večinoma odselili nazaj $v$ Nemčijo. $\vee$ matične države so se odselile tudi manjše skupine Madžarov, Judov, Čehov in Slovakov, ki so zapustili ogromna posestva in zemljišča. Tedaj je postalo očitno, da je kolonizacija »nujna obče-državna potreba«, kot jo je imenoval dr. Milenko Filipović (Filipović 1958, 8-10; Domonji 2000, 19).

Ta kratek zgodovinski sprehod dogajanj v Vojvodini je zgolj bežen oris velikih sprememb, ki so za seboj pustile pestro etnično sestavo današnje Avtonomne pokrajine Vojvodine. Pa si pobližje poglejmo, kako in v kakšnem deležu so se Slovenci znašli na tem ozemlju v posameznih zgodovinskih obdobjih.

\section{Obdobje pred prvo svetovno vojno, ko »Sila kola lomi!«}

Izseljevanje iz slovenskega etničnega prostora pred prvo svetovno vojno je bilo sestavni del evropskih migracij v devetdesetih letih 19. stoletja, ko govorimo o eksploziji prebivalstva v Evropi. Okoli leta 1870 se je začelo izseljevanje iz Avstro-Ogrske, ki je svoj najmočnejši tok doseglo v času od leta 1890 do prve svetovne vojne (Lukšič Hacin 1995, 27).

Okoliščine, vzroke preseljevanj, morebitni slovenski delež ter tedanja razmišljanja Slovencev nam prepričljivo ponazarjajo Kmetijske in rokodelske novice ( $v$ nadaljevanju Novice), ki so bile namenjene najširši slovenski javnosti. Življenjska situacija v 19. stoletju je bila zaznamovana $z$ nenehnimi gospodarskimi krizami, zaradi katerih so propadali mali kmetje. Razni davki, zadolževanje, odškodnine za odkup zemlje in padec cen kmečkih pridelkov zaradi konkurence uvoženih produktov so bremenili njihov položaj. Poleg tega so še naravne nesreče (požari, pozebe, poplave in trtni škodljivci), propad železarstva, razvoj tehnologije, 
železnica marsikomu odvzeli kruh, kar je ljudi prisililo v razmišljanje o odhodu iz domačega kraja (Novice 1865).

Ljudje so se po nasvete in pomoč, kam se izseliti in kako, obračali na Novice. Te so 26. julija 1865 poročale o dopisu iz konjiške okolice, $v$ katerem bralec J. S. piše o tedanjem stanju med prebivalci: »Drugega skoraj ne ostaja, ko zapustiti milo domovino in si drugje domovja iskati ... Al' ni nas malo, polovica hribovskih prebivalcev je, kateri lakoto preživljajo in stokajo pod bremenom dolgov in davkov. Bilo je preteklo leto tako slabo, da marsikatera družina zdaj ves božji teden ne jé nič močnatega, kar jé, je brez zabele, in raztrgana hodi, da si ne upa v cerkev in nima živine, da bi gnoj delala: kako bo pa še za prihodnje, ko se nam še veliko slabše kaže ... Tako nam tedaj ne ostaja kar nič drugega, kot se izseliti.« V pismu uredništvu J. S. pravi, da jih od doma ženeta stiska in sila, v kateri so se mnogi znašli, nikakor pa naj ne bi šlo za »hrepenenje po izselitvi, nemški 'Auswanderungsfieber'... Domovina nam je, se ve, čez vse, al' glad in siromaštvo je najhujše na svetu.«

Jurij Matej Trunk (1912) je v delu Amerika in Amerikanci ugotavljal, da je bilo napačno mnenje, da je uboštvo sililo ljudi v odhod. »Pravo uboštvo ljudi tlači, oslabi, da nimajo moči za izseljevanje.« Kot je zapisal, so družine začele misliti na izseljevanje, ko niso mogle več živeti, kakor so bile navajene, ko so začutile pomanjkanje ali ko jih je prizadela kakšna nesreča, naraščanje novih življenjskih potreb, novi carinski zakoni ali drugo. Izselitev jim je pomenila »up jasnejših in slajših dni«.

Uredništvo Novic je že v prejšnjih izdajah svetovalo, da če že »sila kola lomi«, naj se raje kot $\vee$ Ameriko ljudje preseljujejo $v$ Srbijo ali Banat. Za Ogrsko, Hrvaško, Slavonsko, srbsko Vojvodino s Tamiškim Banatom in Erdeljo so celo poročali o olajšavah, ki so jih bili novi naseljenci deležni, ne glede na njihovo število. Po odloku cesarske vlade 23. 12. 1858 si je bilo treba $v$ omenjenih deželah kupiti vsaj osem oralov zemlje, $v$ zameno pa jim ni bilo treba plačati stroškov prevoza, zidanja hiše, spremljevalnih poslopij in drugih reči. Pri naselitvi večjega števila ljudi je odlok zahteval, da se naseljenci istega naroda in iste veroizpovedi naselijo $v$ istem kraju. Ugodnosti so se nanašale tudi na oprostitev zemljiškega, hišnega davka, davka od dohodkov, dolžnosti dela na cestah in pri vodah zunaj svoje soseske, a le za določen čas. Pa vendarle so Novice morebitne naseljence opozarjale na razlike $v$ uporabnosti zemljišč. Na splošno so bile namreč površine zelo rodovitne, razen krajev med Donavo in Tiso, ki so bili deloma peščeni in manj rodovitni, deloma pa zelo rodovitni in manj obljudeni. Spraševali so se, kdo bo naseljence pravilno usmeril in jim povedal, kam se naseliti. Kot najugodnejšo za naselitev so označili Banat, južne podonavske kraje in bolj hribovske kraje onstran Tise proti Erdelji. Preden se je kdo odločil za selitev, so Novice svetovale preudaren premislek in zastavitev vprašanja: »Ali si ne more drugače nikakor več pomagati? ... Ali jim je mogoče še strpeti doma kaka leta ali ne?« V uredništvu so menili, da 


\section{Lukić \\ »Drugega skoraj ne ostaja, ko ...}

je pri odločitvi o odhodu treba upoštevati več dejavnikov. Priznavali so, da je bil poglavitni nagon in motiv za željo po odhodu izboljšanje življenjskega standarda in stanu, vendar pa so pravili, da nekatere nadloge in stiske utegnejo miniti ali pa ostati za vse dni. Nemalokrat so opozarjali, da se ljudje iz tujine lahko vrnejo še bolj obubožani kot prej (Novice 1865, 237-8).

Minljivost stiske so nekateri skušali rešiti z odhodom v Vojvodino, a le na sezonsko delo, kot velja po navedbah Mihaela Küzmiča (2001) v drugi polovici 19. stoletja za protestantske madžarske Slovence, ki so prebivali na obmejnih agrarnih območjih in jim ukvarjanje s poljedelstvom ni zadostovalo za preživetje. Pri nekaterih se je sezonsko delo spremenilo $v$ izseljenstvo.

Izseljevanje pred prvo svetovno vojno pa ni bilo omejeno zgolj na podeželski živelj. Lesjak, Gader, Reberšček, Zdovc, Benedikt, Majhenšek, Černelc, Župančič, Guček, Sterlet, Ogrinc ... to so slovenski priimki, ki jih najdemo na nagrobnikih starega pokopališča nekdanjega fruškogorskega rudnika rjavega premoga Vrdnik, nemi pričevalci nekdanje slovenske rudarske kolonije $v$ Vrdniku. Slovenski rudarji so med oktobrom 1871 in oktobrom 1907 prišli $v$ te kraje zaradi dela. Leta 1875 jih je prišlo kar 90, kot navaja France Cevc $(2001,314)$, sam Slovenec $v$ Vojvodini in zbiratelj podatkov o rojakih $v$ teh krajih. Okrog rudnika, kjer so $z$ vse večjim prihodom delovne sile rastle rudarske kolonije, naj bi bil poleg srbskega jezika v naseljih Stara in Nova Kolonija povsem običajen tudi slovenski jezik. Slovenci so se v novem okolju precej dobro znašli, o čemer priča lastna rudarska godba na pihala z desetimi godbeniki, med katerimi so bili kar trije bratje Zdovc (Kržišnik - Bukić 1992, 189), kot tudi dejstvo, da je v rudniku delal visoko izobražen kader, med njimi Mihajlo Lesjak, električar, ki je sam konstruiral motor za pogon natresnih žlebov, ter Ivan Peter, ki je izdelal električni vrtalnik (NN 1946a, 1). Glavni direktor je bil nekaj časa inženir Janežič iz Ljubljane, pozneje pa inženir Gusti Šoštarič iz ljubljanske fakultete za montanistiko, ki je bila edina v vsej Kraljevini Jugoslaviji. Cevc (2001) pravi, da »ni bilo jugoslovanskega rudnika, $v$ katerem ne bi bil zaposlen kak rudarski inženir ali nadzornik Slovenec."

Popis iz leta 1948 na območju Vrdnika, okraj Ruma, je med prebivalci naštel 476 Slovencev, leta 1953 pa 439 (Kržišnik - Bukić 1992, 189-90). Trend priseljevanja je postopoma pojenjal in leta 1968 ugasnil, ko so rudnik zaprli zaradi slabega povpraševanja po premogu, ki so ga začeli spodrivati naftni derivati. Po njegovem zaprtju so se delavci porazdelili, največ Slovencev je delo dobilo v sosednjem kamnolomu Rakovac, ki je že imel zaposlene Slovence, med njimi tehničnega direktorja Franca Zupančiča (Cevc 2001). Popis prebivalstva iz leta 1991 pokaže, da je v Vrdniku ostalo slabih 3,3 \% Slovencev od skupno 3.495 prebivalcev (NN 2008). Med njimi tudi Viktor Hvala, »zadnji izvirni Slovenec v Vrdniku«, kot ga je poimenoval Željko Marković, ki je v Dnev- 
niku 17. 10. 2008 zapisal njegovo zgodbo. Viktorjev oče (tudi) Viktor se je leta 1924, po prejetju odpovedi v tovarni porcelana, z ženo Ano in petimi otroki kot ekonomski migrant preselil v Vrdnik, kjer je že živela populacija Slovencev, pretežno zaposlenih v rudniku rjavega premoga. Sin Viktor, ki je pripovedoval zgodbo, se spominja, kako se je pri sedemnajstih letih prvič spustil v dvesto metrov globoko rudniško okno, s ponarejenimi papirji o polnoletnosti, ki jih je priskrbel oče. Marca 1958, ko je v rudniku izbruhnil velik požar, je bil Viktor nadzornik in del tričlanske reševalne ekipe.

Precej Slovencev se je v Vojvodini znašlo tudi ob nastanku Kraljevine Srbov, Hrvatov in Slovencev, zlasti vojaške starešine, ki so jih premestili v različne vojvodinske kraje, kjer je bila srbska vojska zdesetkana v obeh balkanskih in v prvi svetovni vojni (Cevc 2001).

\section{Agrarna reforma in kolonizacija Vojvodine med obema svetovnima vojnama}

Agrarna reforma in kolonizacija sta bila »dva družbena procesa komplementarne narave« (Gaćeša 1995, 238), ki sta pogojevala obsežne migracije prebivalstva in odločilno vplivala na oblikovanje raznolikega demografskega okvirja (Đurđev 1995, 184), v katerem je bila Vojvodina tako objekt kot subjekt kolonizacije (Gaćeša 1984, 372).

Kolonizacija, »organiziran, zakonsko normiran migracijski proces«, se je izvajala na osnovi Uredbe o prostovoljcih, Odloka o začasnem naseljevanju prostovoljcev ter drugih pravnih predpisov. Kljub temu se je začela izvajati, še preden je bilo povsem določeno, kdo je lahko kolonist, kakšen je načrt naseljevanja in katera bo zemlja za naseljevanje (Gaćeša 1995, 367, 372). Uredba o prostovoljcih je na primer zahtevala, da si naseljenci zgradijo hiše $v$ obdobju treh let po prejemu posesti. $V$ nasprotnem primeru so izgubili pravico do lastnine nad posestjo, ki jo je prevzelo zvezno ministrstvo za agrarno reformo. Obstajala je tudi možnost začasnega naseljevanja prostovoljcev, kjer je država plačevala zakupnino zemljišča, v zameno za to, da jo je prostovoljec obdeloval (Gaćeša 1968, 157-65).

Med svetovnima vojnama se je pojavil agrarni problem, posebej zaradi prevlade ogromnih zemljišč, ki so bila $\vee$ lastništvu zemljiščne aristokracije, večinoma tujega etničnega porekla (Đurđev 1995). Z izvajanjem agrarne reforme, ki je potekala v skladu s predhodno sprejetimi določbami iz leta 1919, so se spremenili agrarno-posestni odnosi, a se je problem nadaljeval tudi po drugi svetovni vojni (Gaćeša 1995). Osnovni cilj agrarne reforme, ki se je izvajala prek Agrarne direkcije v Novem Sadu (pozneje v Beogradu) in njenih županijskih direkcij, je bila likvidacija najemniškega odnosa $v$ poljedelstvu, tako da je bil obseg razlastitve odvisen od individualnega odnosa lastnika do zemlje, ker je zakon pravil, da je zemlja pripadla tistemu, ki jo je obdeloval. Tako se 


\section{Lukić \\ »Drugega skoraj ne ostaja, ko ...}

je kot osnovni socialno-politični cilj reforme izpostavilo izenačevanje agrarno-posestnih odnosov. Ker pa je agrarna reforma potekala vzporedno s kolonizacijo, je imela tudi nacionalno-politični cilj: ustvariti v koloniziranih naseljih slovansko večino (Gaćeša 1975, 68, 224; Đurđev 1995, 62).

Pri kolonizaciji Srema, ki je potekala od leta 1919 in se je večinoma končala do dvajsetih let 20. stoletja, z nekaterimi »sporadičnimi naseljevanji« še $v$ tridesetih letih, je šlo, za razliko od Bačke in Banata, za kolonizacijo manjšega obsega z majhnim številom naseljencev in omejenimi možnostmi za njihovo premeščanje, kar je vplivalo na sistematičnost in trajnost v naseljevanju Srema. Naseljevanje je imelo izrazito socialno-ekonomsko komponento, saj so zemljo dobili tuji naseljenci, s čimer so onemogočili pridobitev veleposestniške zemlje domačim, sremskim agrarnim interesentom. Odvzeta veleposestniška posest se je porazdelila med kolonizacijske subjekte: $48 \%$ te posesti je pripadlo 886 prostovoljcem, med njimi so bili trije Slovenci, dva iz Kranja in eden iz Krškega, 38 \% mestnim agrarnim interesentom, 13 \% kolonistom, optantom, avtokolonistom in beguncem, nekaj pa je ostalo javnega dobra (Gaćeša 1975). Rezultat agrarne reforme in kolonizacije Srema je bil najbolj očiten v ustanavljanju novih naselij in v spremembah nacionalne in socialne strukture Srema.

Agrarna reforma v Bački je bila obsežnejša, zahtevala je načrtno in sistemsko delovanje, zato je potekala $v$ treh fazah. V prvi fazi (19191924) se je veleposestniška zemlja izdajala v enoletni zakup in pozneje v štiriletni. V drugi fazi (1924-1931) se je zakup odvzete veleposestniške zemlje obnavljal vsako leto, vse do izteka štiriletnega zakupa. In v zadnji fazi (1931-1941), so se pravno sankcionirali rezultati, doseženi do sprejetja Zakona o likvidaciji agrarne reforme (Gaćeša 1968). Ob začetku leta 1939 je bilo v Bački 52.615 agrarnih naseljencev, ki so dobili $53,18 \%$ odvzete veleposestniške zemlje, medtem ko so veleposestnikom prepustili ostalo (Gaćeša 1968, 111, 241). Za razliko od sremske kolonizacije je bačka imela nacionalno-politično obeležje. Od naseljevanja se je namreč pričakovalo, da bo utrdilo etnično strateške pozicije severnih predelov predvojne Jugoslavije in preprečilo ekonomski naval nemškega življa. Kolonizacijski subjekti v Bački so bili prostovoljci (borci in neborci), kolonisti s splošnimi pogoji in optanti. Med novo nastalimi naselji je tako bila zanimiva Kolonija slepih Vetrnik, naseljena s 50 borci solunske fronte, ki so izgubili vid in med katerimi se omenja tudi naseljenec iz Celja (Gaćeša 1968, 203-4).

Kolonizacija Banata je sovpadala z izvajanjem agrarne reforme od leta 1919 do 1941, vendar sta se procesa odvijala v različnih intenzivnostih intervalih. Kolonizacijski subjekti so naseljevali predvsem posestva zasebnega lastništva, občinske, cerkvene posesti, državno dobro in Pančevački rit. Med 42 novimi naselij je pri Ečki 231 revnih družin prejelo zemljo za naseljevanje. Med družinami, ki so prihajale predvsem iz 
drugih predelov Vojvodine in Srbije, je bila tudi ena družina iz Bosne in ena iz Slovenije (Gaćeša 1972).

Kot bomo videli v nadaljevanju, sta kolonizacija in agrarna reforma med obema vojnama dosegli zgolj polovične rezultate, zato so državne oblasti poskusile ponovno po drugi svetovni vojni (Gaćeša 1968, 281).

\section{4 »Od Rač pri Mariboru in Rajhenburga do Aranđelovca«, slovenski izgnanci na poti v Vojvodino med drugo svetovno vojno}

$\checkmark$ tem obdobju je bilo v Srbijo izgnanih nekaj tisoč Slovencev. Prvotni načrt iz leta 1941 je predvidel deportacijo 260.000 Slovencev na ozemlje med Donavo in Kragujevcem. Pozneje je prišlo do znižanja predvidenega števila na 179.000 , prostorsko pa so v okvir naseljevanja vključili še Pavelićevo Neodvisno državo Hrvaško. Načrt je predvidel deportacijo $v$ štirih valovih. S prvim valom so se želeli lotiti slovenske inteligence, z drugim bi deportirali osebe, ki so se naselile na Spodnjem Štajerskem po letu 1914, z izjemo rasno dragocenih in politično nekompromitiranih oseb in zaposlenih v rudarstvu. Tretji val naj bi zaobjel obsavski in obsotelski pas, na katerem bi se naselili Kočevarji in drugi Nemci, s četrtim valom pa bi se znebili tistih, ki ne bi bili sprejeti v štajerski Heimatbund (Roš 1967, 14).

Po sprejetju osnovnih namenov so sklenili, da v prvem valu nasilno izselijo 5000 Slovencev iz Spodnje Štajerske. Za nekatere so določili vstopno postajo Rače pri Mariboru, za druge Rajhenburg ter izstopno srbsko postajo Aranđelovac. Sklenili so, da bosta vozila dva vlaka tedensko s po tristo ljudmi, v zadnjem tednu pa dnevno dva vlaka. Med prvim in drugim štajerskim valom so transportirali približno 4000 slovenskih intelektualcev iz Gorenjske. Za njih je bila vstopna postaja Šentvid pri Ljubljani, izstopna Aranđelovac. Podrobnejših podatkov o transportih iz Gorenjske ni. Po Franu Rošu naj bi odšlo šest transportov s povprečno štiristo osebami. Transporti v Srbijo so potekali preko Zagreba, Slavonskega Broda, Sarajeva in Višegrada. Vstopna postaja v okupirani Srbiji je bila Vardište. Večina transportov je šla skozi Aranđelovac, kjer so se po dvodnevnem počitku razporedili za nadaljnja potovanja proti drugim srbskim krajem (Roš 1967, 15, 19, 23).

Spremljati število izgnanih v Srbijo je bilo težko, saj so se natančno beležile samo osebe, prispele z železniškim transportom. Po teh podatkih je Srbija iz rajha sprejela 6720 slovenskih izgnancev. Prispele Slovence so v skupinah pošiljali predvsem v osrednje in južne srbske kraje (Ferenc 1968, 235, 421). Drugačni so nemški uradni podatki, ki pričajo o 6694 izgnanih: kar 38 \% je bilo otrok, 33 \% moških in 29 \% žensk. Šlo naj bi večinoma za inteligenco, ljudi s prostimi poklici, državne in zasebne nameščence, manj je bilo delavcev in kmetov. Duhovnike in redovnike so poslali v samostane, od svetnih so Gorenjci odšli v Sremske 


\section{Lukić}

»Drugega skoraj ne ostaja, ko ...

Karlovce, drugi na Hrvaško. Večina se je kmalu preselila v Ljubljansko provinco, tako da je bilo izseljenih oseb 7117.

Fran Roš (1967, 22-4) kot glavni razlog za različne podatke o izgnancih omenja partizansko dejavnost, ilegalo in obrambo, sčimer so se izognili aretaciji in deportaciji. Skoraj petina vseh prispelih Slovencev je v začetku leta 1941 zapustila Srbijo, saj so mnogi dobili dovoljenje za naselitev v ljubljanski provinci. Druge je sprejel Banat, sicer še formalno pod Srbijo, vendar zaradi močne nemške manjšine podrejen nemški okupacijski oblasti.

Ohranjeni transportni seznami pričajo, da je bilo od 6. do 10. julija 1941 pet transportov v Srbijo. Med njimi se za datum 10. 7. vpisuje končna postaja Sremski Karlovci za 169 oseb, deportiranih iz Gorenjske, in 500 oseb, deportiranih iz taborišča Šentvid nad Ljubljano. V Sremskih Karlovcih najdemo tudi pregnano duhovščino. Za njimi so poslali družine, sorodnike, ki so bili v taborišču v Slavonski Požegi. Duhovnike so razmestili po enajstih različnih pravoslavnih samostanih. Konec avgusta 1941 so jih čez Zagreb poslali v Ljubljano, od tu pa jih je večina odšla v cistercijanski samostan $v$ Stični. V sremskih pravoslavnih samostanih je tako ostalo devet duhovnikov (Ferenc 1968).

Državno ravnateljstvo za obnovo oktobra 1941 navaja, da je bilo v Sremski Mitrovici razvrščeno 34 družin slovenskih izgnancev in v Šidu 30 družin. Gre za dva kraja v Sremu, ki je tedaj spadal pod Neodvisno državo Hrvaško (Ferenc 1968, 449-50).

Drago Predan iz Celja, sam izgnan v Srbijo, za območje Banata priča, da so tu že v predvojnem času živeli Slovenci. Čeprav na ta del ozemlja ni bil usmerjen noben transport izseljencev, se je tu naselilo nekaj sodnikov, finančnih in drugih nameščencev, saj so bile življenjske razmere ugodnejše. Septembra 1942 sta z bratom in družinama prišla iz Vrnjačke Banje v Belo Crkvo v vzhodnem Banatu. Drago Predan je urejal račune o plačilu trošarine na alkoholne pijače, brat pa je delal $v$ carinarnici. »Ob prihodu v Belo Crkvo so tamkajšnji srbski učitelji izkazali najljubeznivejšo pozornost«, ki se je kazala v opremljeni enodružinski hiši. »Poiskali so nas Slovenci, da nas pozdravijo, tako sodnika dr. Tribnik in Verlič, nameščenci Rupnik, Bohanec, Simončič, Remec, Rebec in še drugi« (Roš 1967, 391). Domačini so ga povabili k sodelovanju pri zgraditvi nove ljudske oblasti, nakar so se priključili vsi Slovenci. Približno štirideset Slovencev iz Bele Crkve je v začetku oktobra 1944 ustanovilo organizacijo Osvobodilne fronte, ki ji je predsedoval Drago Predan. Zagotovili so si gostilniške prostore, t. i. »Slovenski dom«, kjer so se shajali, politično in kulturno udejstvovali. Predan je pozneje postal tudi dirigent sindikalnega mešanega pevskega zbora. Osnovali so društvo in ga poimenovali po Francu Rozmanu - Stanetu. Konec novembra so iz Slovenije prišli slovenski partizani, ki so bili določeni za šolanje v vojaških šolah Sovjetske zveze. Ravno v Beli Crkvi so čakali na rusko transportno letalo. »Obiskali smo jih in toplo so nas sprejeli. 
Drug drugemu smo pripovedovali, kar smo v letih vojne doživeli.« Pred koncem vojne je v Belo Crkvo prišel transport Bizeljčanov, s katerimi so skupaj čakali na osvoboditev Slovenije. Številni so v Banatu začeli obnavljati vinograde in sadovnjake. Na mestni osnovni šoli so za otroke Bizeljčanov odprli slovenski oddelek, kjer sta poučevali Lea in Frančiška Predan (Roš 1967, 460-1).

Svoj delež so slovenski izgnanci prispevali tudi na sremski fronti. Vključeni v slovenski bataljon so sodelovali v bojih pri vasi Komletinci, kjer so bili ranjeni štirje borci, padlo pa jih je štirinajst. Januarja 1945 je na vzpetini nad Opatovcem v boju padlo 71 borcev, številni so bili pogrešani, nekateri ujeti. $V$ slovenskem bataljonu, ki mu je nekaj časa poveljeval Albin Dolščak, naj bi padlo najmanj 147 Slovencev (Ferenc 1968, 434). Po pričevanjih Marte Kolarjeve iz Celja sta se njena otroka novembra 1944 javila v narodnoosvobodilno vojsko Jugoslavije. Sin je bil udeleženec ofenzive iz Srbije v Slovenijo, hčerka pa je ustanovila in vodila domove otrok ubitih staršev v Banatu (Roš 1967, 337, 467).

Slovenski izgnanci v Srbiji so se vrnili v domovino v skladu $z$ načrtom odseka za repatriacijo, po katerem so se vrnili sprva izgnanci iz stare Srbije, sledili so Banat in Srem ter Beograd (Ferenc 1968, 435).

\section{5 »Delati hitro in zanesljivo«, kolonizacija po drugi svetovni vojni}

Kot omenjeno, je kolonizacija Vojvodine sledila tudi po drugi svetovni vojni od leta 1945 do 1948. »Organizirano metanastazično premikanje« iz vseh jugoslovanskih območij, kot jo imenuje Gaćeša (1995, 463), je Vojvodini prineslo novo strukturo prebivalstva.

Državno in partijsko vodstvo nove Jugoslavije je leta 1945 v začasni vladi Demokratične federativne Jugoslavije ustanovilo ministrstvo za kolonizacijo (Gaćeša 1995, 464), ki je z dvema dokumentoma, Deklaracijo začasne vlade DFJ in Zakonom o agrarni reformi in kolonizaciji ( $v$ nadaljevanju zakon), postavilo pravno-politični okvir in pogoje za naseljevanje. Neposredne priprave so zajemale niz organizacijskih del, od prevoza in sprejema do nastanitve kolonistov $v$ vojvodinska naselja (Gaćeša 1984, 298).

Izvedba je bila $v$ rokah ministrstva za poljedelstvo, osnoval pa se je tudi zvezni Agrarni svet DFJ. Po zakonu so razlaščeno zemljo tvorili (NN 1945, 3) presežki obdelovalne zemlje poljedelskih posesti z zakonom določenega maksimuma; presežki posesti nad 5 hektarjev, kadar lastniki niso bili poklicno poljedelci in zemlje niso obdelovali sami s svojo družino, temveč z zakupom ali najeto delovno silo; obdelovalna zemlja državljanov nemškega rajha in oseb nemške narodnosti, ki se je od 21. novembra 1944 zasegla po odločitvi AVNOJ-a; obdelovalna zemlja narodnih sovražnikov in drugih oseb, zasežena na podlagi odločitve ljudstva, ter zemlja, ki jo je država ločila od svojega lastništva in 


\section{Lukić \\ »Drugega skoraj ne ostaja, ko ...}

se je podelila siromašnim obdelovalcem zemlje. Med razlaščeno zemljo, ki je v celoti prešla v državno lastništvo z vsemi stavbami na njej, živino in drugim poljedelskim inventarjem, brez odškodnine lastnikom, so bile: velike posesti v skupni površini nad 45 hektarjev ali 25 do 35 hektarjev obdelovalne zemlje (njive, travniki, sadovnjaki, vinogradi), ki so se izkoriščale z zakupom ali najemom delovne sile; posesti v lasti bank, podjetij, delničarskih družb in drugih zasebnopravnih in pravnih oseb, določenih z zakonom (izjema so bili deli zemljišč, ki so se lastnikom pustili za industrijske, znanstvene, kulturne in druge družbeno koristne namene); zemljiške posesti cerkev, samostanov in vseh vrst verskih ustanov ter posesti, ki so med vojno iz katerega koli razloga ostale brez lastnika ali brez pravnega naslednika (NN 1945, 3).

Za prvo obdobje je veljal slogan »delati hitro in pravilno«, kar je pomenilo zbrati vsa tehnična sredstva za delo, delovno silo ter že $v$ sami pripravi biti natančen in dobro seznanjen z zakonom, da bi ga bilo mogoče pravilno in smiselno izvajati. Drugo obdobje je zajemalo razdeljevanje zemlje (Gvozdenac 1946), ki je bila v okviru zakona vpisana v zemljiško knjigo kot privatna lastnina osebe, ki jo je obdelovala.

Razlaščena zemlja se je najprej razdelila med agrarnimi interesenti prvenstveno v njihovem kraju prebivanja ali njihovi federalni enoti ter med borci jugoslovanske armade, ki so se prijavili in obvezali, da bodo z družino obdelovali posest. Za borce invalide, z družino ali brez nje, ki niso bili sposobni obdelovati dobljene zemlje, so bile oblikovane posebne kolonije na specifičnih zemljiščih, primernih za vzgajanje različnih kulturnih rastlin. $V$ takšnih kolonijah so bile zgrajene šole, domovi in obrtniške delavnice, po potrebi z individualnimi stanovanjskimi stavbami in vrtovi (NN 1945, 3).

$V$ mestih so potekale $t$. i. konference za delitev zemlje, na katerih so se interesenti sestajali z agrarnimi komisijami, ki so sestavile svoje predloge. Časopis Slobodna Vojvodina je tedaj poročal, da so se v Banatu in Bački na takih konferencah ljudje »skoraj v vseh primerih" strinjali s predlogi komisije, katerih del so bili tudi predstavniki agrarnih interesentov sami, ki so zagotavljali pravično razdeljevanje zemlje, »hiš, postelj, posteljnine, posodja in oblačil. Pri razdelitvi se upošteva številnost družine. Komisije, ki opravljajo ta posel, pogosto ponoči ne spijo in pogosto iščejo pomoč.» Interesenti so obljubljali, da bodo dosegali čim večjo stopnjo poljedelske proizvodnje in tako zadovoljevali potrebe ljudi v prehrani, zato so prihajali na konference »kot na slavje«, saj je bila dodelitev zemlje »uresničitev večnega sna delovnih ljudi na podeželju, ki so jim bili odvzeli zemljo« (NN 1946b, 1). O kolonistih, ki so prihajali iz krajev, kjer so živeli v drugačnih razmerah in v največ primerih s seboj niso prinesli ničesar, ne pohištva ne poljedelskega orodja (Čalar 1946, 1), je Slobodna Vojvodina poročala: »Prihajajo na plodno vojvodinsko zemljo, da jo sprejmejo in obdelujejo. Zemlja postane njihova. Prejeli jo bodo v večno uživanje. Država družinam kolo- 
nistov poleg zemlje daje tudi hišo, živino, pohištvo in obleko. Toliko kot imajo vsega na voljo.«

$\checkmark$ tem obdobju ločimo dve vrsti kolonizacije: notranjo, premikanje in preseljevanje skupin v okviru ene federalne enote oziroma narodne republike, ter zvezno ali zunanjo, ki je zahtevala premike iz vseh jugoslovanskih enot v Vojvodino (Gaćeša 1984, 283). Od celotnega števila kolonistov jih je kar 95,4 \% prišlo z drugih območij Jugoslavije, notranjih kolonistov je bilo 4,3 \%, kolonistov iz tujine pa 0,3 \% (Đurđev 1995, 65)

Dejansko naseljevanje se je zgodilo po koncu vojne, julija in avgusta leta 1945 , ko so popisali zapuščene hiše in ugotavljali razsežnosti agrarne zemlje, ki je na voljo. Sprva so koloniste napotili v Novi Sad in druga središča, kjer so jih seznanili z osnovami, kot so številčna in geografska razporeditev naseljencev (Beljanski 1986). V obdobju od leta 1945 do 1948 je bilo v Vojvodini naseljenih 37.544 družin iz vseh jugo-

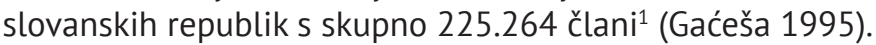

Po popisu prebivalstva 15. maja 1948 je bilo razmerje med priseljenim prebivalstvom in staroselci v Vojvodini $63,9 \%: 36,1 \%$. Celotna Srbija tedanje FLRJ je imela 78 \% staroselcev in $22 \%$ priseljencev. Delež priseljencev pojasnjuje dejstvo, da je Srbija sprejemala selitvene tokove iz vseh ljudskih republik tedanje FLRJ, med katerimi je bil najmočnejši tok iz Hrvaške s kar 38 \% vseh selitev, Bosna in Hercegovina je dala 33 \% migrantov, Črna gora 15 \%, Makedonija 10 \% in Slovenija 4 \% (Bukurov 1957). Deleže dodatno pojasnjuje načrt naseljevanja z »naseljeniškimi kvotami«, po katerih je iz Bosne in Hercegovine prišlo 12.000 borčevskih družin, iz Hrvaške 9000 , Črne gore 7000, iz Srbije s Sandžakom 6000, ravno toliko iz Vojvodine, iz Slovenije 3000 družin in iz Makedonije 2000. Družine slovenskih borcev so se naselile v Banatu (Gaćeša 1984, 294).

Vojvodina je sprejela več priseljencev kot katera koli ljudska republika, kar dve tretjini priseljencev celotne Srbije ali tretjino medrepubliških migrantov. Iz Slovenije jih je sprejela 0,4 \%. Znotraj njenega ozemlja so se izpostavile nekatere administrativne enote $s$ pretežno priseljenim prebivalstvom, kot je bil Novi Sad z absolutno večino priseljenega prebivalstva (Bukurov 1957).

\section{1 Kolonizacija Slovencev in prvi prihod v Gudurico}

Razporeditev borcev na območju Vojvodine je urejal dokument, sestavljen s strani Agrarnega sveta in Komisije za naseljevanje borcev, ki so jo tvorili po en predstavnik ljudske vlade posameznih federalnih enot jugoslovanske države. Ljudska vlada republike Slovenije je 28. no-

$1 \vee$ stroki je splošno sprejemljiva ocena, da je naseljenska družina po drugi svetovni vojni imela v povprečju šest članov (Stipetić 1954). 


\section{Lukić}

»Drugega skoraj ne ostaja, ko ...

vembra 1945 za delegata za naseljevanje Slovencev s sedežem v Vršcu imenovala Katarino Špur. Razporeditev je zahtevala, da se borci kolonisti iz Slovenije naselijo v bačko-palanačkem in kulskem okraju, predvidena naseljenska kvota pa je znašala 3000 družin (Gaćeša 1984).

Kolonizacija se je začela s pozivom Ministrstva za poljedelstvo Ljudske vlade republike Slovenije 16. septembra 1945, še pred začetkom same agrarne reforme in notranje kolonizacije $v$ Sloveniji. Na poziv se je do konca leta $" z$ območja vse Slovenije in dela slovenskega Primorja ... odzvalo 1776 borcev, invalidov in žrtev fašističnega terorja ...«. Očitno je bilo, da predvideni plan naseljevanja ne bo izpolnjen. Krivdo za polovičen uspeh so pripisovali propagandi slovenskega partijskega vodstva, ki je nasprotovalo izseljevanju iz slovenskega Primorja, kjer je bilo največje zanimanje za kolonizacijo, češ »kdo ve, tam lahko pride do plebiscita«. Nato je LR Slovenija spremenila svojo kvoto za 1500 družin, s tem da je med preostalimi 1500 mesti moralo ostati 900 mest za borce iz slovenskega Primorja, ki bodo obdelovali zemljo. 20. januarja 1947 se je LR Slovenija odpovedala tudi tem mestom in kvoto s prvotnih 3000 mest zmanjšala na 600 (Gaćeša 1984, 256-7, 324). Neizpolnjene kvote je Komisija za agrarno reformo in kolonizacijo pri Vladi FLRJ 16. aprila 1947 porazdelila med druge ljudske republike (Gaćeša 1984, 343).

Po zaključenih pripravah v Sloveniji je prva skupina slovenskih kolonistov odšla proti Vojvodini in 1. novembra 1945 prispela v Gudurico. Kmalu po njihovi nastanitvi je Ministrstvo poljedelstva Ljudske vlade republike Slovenije zahtevalo od ministrstva za kolonizacijo, da pospeši odhod slovenskih kolonistov $v$ Vojvodino, vendar so naleteli na obrazložitev, da to »trenutno ne pride $v$ poštev ..., ker so bila na dnevnem redu preseljevanja iz BiH, Hrvaške in Črne gore. Promet je bil preobremenjen s transportom kolonistov.« Drugi transport je 24. 11. 1945 v Veliko Gredo pripeljal 58 družin z 221 člani, ki so se razporedili v Plandište in Veliko Gredo. S tretjim transportom je 28.1.1946 prispelo 73 družin z 291 člani, od katerih se jih je največ naselilo v Sečenovo, Vršac, Veliko Gredo in Gudurico (Gaćeša 1984, 4, 325-326).

Za avgust leta 1946 uradni podatki glavne komisije za naseljevanje borcev v Vojvodino navajajo naselitev 623 slovenskih družin z 2625 člani, in sicer: v Veliki Gredi, Vršcu, Gudurici, Mariolani, Sečenovu in Sonti (Bačka) (Gaćeša 1984, 324). Po popisu iz leta 1948 je 1538 kolonistov iz Slovenije naseljevalo 15 vojvodinskih naselij v občinah: Apatin, Bač, Inđija, Vršac, Pečinci, Plandište, Pančevo, Sremska Mitrovica, Sombor, Vršac in Zrenjanin (Đurđev 1995, 87-89.)

Podatki o številu naseljenih slovenskih kolonistov po drugi svetovni vojni se razlikujejo od avtorja do avtorja.Zanimiva je metoda dr. Branislava Đurđeva (1995), ki je upošteval politično-teritorialno razdelitev Jugoslavije na okraje iz leta 1948, za Vojvodino delitev na občine iz leta 1971 in na demografske rajone II. stopnje iz leta 1961. Tako je Sloveni- 
jo razdelil na dva demografska rajona: vzhodno in zahodno Slovenijo, pri čemer je bilo več kolonistov iz vzhodne kot zahodne Slovenije. Iz vzhodne Slovenije jih je bilo največ iz krškega in lendavskega okraja, iz zahodne pa ljubljanskega in goriškega okraja.

Samo Ministrstvo za poljedelstvo in gozdarstvo LR Slovenije je Komisiji za agrarno reformo in kolonizacijo pri Vladi FLRJ posredovalo naslednje podatke: preseljenih je bilo 591 družin z 2836 člani, v razmerju 49 \% moških in 51 \% žensk. Od tega se je do začetka leta 1948 v Slovenijo vrnilo 131 družin, med katerimi je bil odstotek moških in žensk enak kot pri preseljenih. Tako naj bi bilo takrat $v$ Vojvodini 460 slovenskih družin po poreklu največ iz murskosoboškega ( 90 družin), lendavskega, krškega, jeseniškega, novomeškega, črnomaljskega in ptujskega okraja (20 družin) (Gaćeša 1984, 326-7).

\section{2 »Prehrana je (bila) preveč enostavna!« - v slovenskem naseljenskem rajonu v Banatu}

Slovenski kolonisti so se v $96 \%$ primerov naselili v južni Banat. Od skupnega števila se jih je kar 95,3 \% oziroma 1517 naselilo v občini Vršac in Plandište (Đurđev 1995). Po nekaterih navedbah je bila kolonizacija zaključena septembra leta 1946 s preseljevanjem 801 družine v slovenski naseljenski rajon v južnem Banatu, ki je zajemal Veliki Gaj, Vlajkovac, Veliko Središte, Veliko Gredo, Vršac, Gudurico, Jermenovce, Mariolano, Sečenovo, Stari Lec (okraj Vršac), Boko in Hrvatsko Neuzino (okraj Jaša Tomić) (Gaćeša 1984, 324).

Osnova za naselitev južnega Banata so bili ogromni kompleksi rodovitne zemlje, ki so jo dobili kolonisti, večinoma borci NOB, ki so izgubili premoženje ali so imeli malo zemlje, ter poljedelski delavci, ki so uresničili svojo željo imeti lastno zemljo, kar je posebej veljalo za prišleke iz Prekmurja in Bele krajine. Bili so primeri, da so prišli ljudje, ki prej niso nikoli obdelovali zemlje, a jih je njihova tedanja gmotna situacija prisilila, da zgrabijo ponujeno priložnost. Transporti za odhode $v$ Vojvodino so se oblikovali že v Sevnici, od koder so z vlakom prihajali v Vršac, od tu pa je potekalo nadaljnje razporejanje po naseljih, pri čemer se je upošteval kraj, od koder so kolonisti prišli. Sami so organizirali, že $v$ Sevnici ali pa kar med potjo, kmečke zadruge in izbrali zastopnike, ki so pozneje sodelovali pri komisijah za podeljevanje osnovnih stvari. $\checkmark$ vsakem naselju je bila komisija, ki je, upoštevajoč število družinskih članov, delila kolonistom zemljo, živino, hiše, opremo, oblačila in hrano. S seboj niso prinesli ničesar, saj so bili naseljenci žrtve fašizma, ki jim je po vojni malo ostalo (Pak 1963, 400-1).

Številčni pregled izseljevanja po podatkih, ki jih je zbral Mirko Pak (1963) na podlagi knjige državljanstva, ki je vodena od leta 1950 dalje za 1495 Slovencev, nam oriše tedanje družbeno-gospodarske razmere posameznih slovenskih okrajev. Iz ljubljanskega okraja je zaradi močne 
propagande in socialnih problemov odšlo kar 80 družin, večinoma iz Cerknice in Ljubljane. Mirko Pak pravi, da se ni čuditi velikemu številu kolonistov tudi iz drugih slovenskih mest, saj je bilo dosti krajev s slabo razvito industrijo ali sploh brez nje. Iz celjskega okraja je odšlo 55 družin, predvsem iz Celja, iz trboveljskega okraja 52, večinoma iz Brežic. Kolonisti iz okrajev Murska Sobota in Novo mesto so se najhitreje in $\checkmark$ največji meri vračali $v$ domovino ali odšli drugam. Iz novomeškega okraja je odšlo 64 družin, predvsem iz Šentruperta, Lopate in Bojanje vasi, iz murskosoboškega okraja 42 družin, prednjačil je jugovzhod Prekmurja. Kolonisti iz teh krajev so se $v$ največjem številu vračali v domovino. Po podatkih Paka je leta 1946 kar 40 družin odšlo nazaj $\checkmark$ Prekmurje. Zaradi hitrega procesa povratništva njihov prihod ni bil zabeležen. Drugačne so bile priložnosti v Mariboru, kjer je industrija zaposlila številno prebivalstvo. Od tu tudi razlog, da so mnogi kolonisti iz Banata odšli za leto ali dve v Maribor in se nato vrnili v Banat. Tako so si zagotovili dvojni zaslužek. Iz mariborskega okraja je zabeležen odhod 40 družin. Iz kranjskega so se izseljevale družine predvsem z Jesenic, iz koprskega okraja pa so odhajale predvsem iz Kopra in Žirja, medtem ko je iz goriškega in kočevskega okraja zaznano najmanjše število kolonistov. Za njih so bili rezervirani domovi v Banatskem Plandištu, a jih je prišlo manj, kot se jih je prijavilo. Majhen delež kolonistov iz koprskega, kočevskega, goriškega okraja Pak (1963) pripisuje določitvi zahodne meje takoj po drugi svetovni vojni in izpraznjenosti Kočevskega.

Kot smo že omenili, so v Banatu, poleg priseljencev iz preostale Srbije, Makedonije, Hrvaške, Bosne in Hercegovine ter Trsta, Slovenci naselili t. i. slovenski naseljenski rajon, ki je $v$ največji meri zajel naselja Gudurico, kamor so kolonisti prispeli v petih transportih med novembrom 1945 in majem 1946, Veliko Gredo, ki so jo naselili v šestih valovih od novembra 1945 do marca 1946, ter Banatsko Plandište, ki je bilo naseljeno v času od septembra 1945 do septembra 1946 (Pak 1963, 408-10).

Pozneje so se kolonisti selili iz naselja v naselje in spremenili sliko naselitve. Zgodilo se je, da so zapustili zemljo $v$ enem naselju in dobili prav toliko zemlje $v$ naselju, kamor so se preselili. Ob tem je preseljevanje Slovencev potekalo znotraj štirih naselij, naseljenimi s slovenskimi kolonisti. Na ta način se je obdržala strnjenost, ki jim je lajšala življenje v novem okolju. Dokaz so glavne ulice v Gudurici, med kolonizacijo izključno slovenske: Prešernova, Župančičeva, Cankarjeva, Gordanova, ulica Komandanta Staneta ter Titova in Prešernova ulica v Veliki Gredi. Izjema je bil Vršac, kjer zaradi terena strnjeno naseljevanje ni bilo mogoče (Pak 1963, 402).

Podeljevanje zemlje $v$ naštetih banatskih naseljih je bilo različno. Štiričlanska družina je največ zemlje dobila $\vee$ Banatskem Plandištu (štiri hektarje in 68 arov), sledi Velika Greda, Vršac, najmanj zemlje pa 
so dobili v Gudurici (Pak 1963, 401). Bistvenega pomena v prvih letih bivanja na novi zemlji je bilo že omenjeno ustanavljanje kmetijskih zadrug. V Banatskem Plandištu sta obstajali dve, ki sta se pozneje združili v eno. V Veliki Gredi sta februarja 1946 nastali zadrugi Tone Tomšič in Stane Rozman, ki sta bili zadolženi za podeljevanje zemlje in organizacijo skupnega dela na poljih, kar je bila posledica pomanjkanja strojev in živine. Podobno sta se v Vršcu leta 1946 organizirali dve, Titan in Triglav, ki sta bili namenjeni izključno Slovencem. Leta 1956 je zadrugo zapustila večina Slovencev in poiskala delo drugje. Tudi v Gudurici sta obstajali Zvezda in Heroj Stane, ki sta se pozneje preoblikovali v enotno Slogo za Slovence, ki je do decembra 1946 štela 40 družin. Povsod so bile zadruge pomemben gospodarski člen, saj so se $v$ njihovem okviru reševali številni problemi. Na primer $v$ Gudurici so $s$ pomočjo zadruge uspeli elektrificirati naselje (Pak 1963, 414).

Začetne težave, $s$ katerimi so se družine spopadale, so bile pomanjkanje stavbnih objektov, premalo živine, saj je ena glava prišla na več družin, pomanjkanje obdelovalnih strojev in tudi težave s prehrano (Pak 1963, 401). Bojan Lovše, takratni delegat Ljudske vlade Slovenije, $\mathrm{s}$ sedežem $\vee$ Vršču, je obvestil glavno komisijo za naseljevanje borcev o določenih problemih z nastanitvijo in oskrbo kolonistov: "primanjkuje sol, sladkor, petrolej, prehrana je preveč enostavna, še posebej ob pomanjkanju krompirja, fižola in zelenjave« (Gaćeša 1984, 325). V Gudurici so sklicali sestanek, kjer so Slovencem predlagali, naj uživajo več mastne hrane, da bi preprečili tuberkulozo in okrepili svoje fizične sposobnosti. Drugačno podnebje, med drugim veter, pomešan $s$ prahom, je bilo precejšna ovira za življenje. Po več letih bivanja $v$ teh krajih so se nekateri pritoževali, »da jih veter duši, poleti pa jim velika vročina krati spanec. « Nasvet o uživanju bolj mastne hrane so podprli zdravstveni organi, zato ga je večina upoštevala. Težave so imeli tudi $z$ drugačnim načinom obdelovanja, orodjem in sredstvi, kot so jih bili vajeni v Sloveniji. Mnogi pred prihodom niso obdelovali zemlje ali pa se kot nekdanji poljedeljski delavci niso takoj znašli. Malo je bilo tistih, ki so se zaposlili kot uslužbenci, pa vendarle je bil v Gudurici od leta 1946 do 1952 župan Slovenec (Gaćeša 1984, 415).

Poleg zadrug so kolonisti osnovali tudi prosvetna društva in šole, $\checkmark$ katerih so poučevali slovenski učitelji kolonisti. V Gudurici so že leta 1946 ustanovili prve štiri razrede slovenske osnovne šole z okrog 60 učenci. Ti oddelki so obstajali vse do leta 1955. Tudi v Vršcu, Veliki Gredi in Banatskem Plandištu so kmalu organizirali štirirazredne slovenske osnovne šole $z$ dvema učiteljema, ki pa so jih do leta 1954 vse ukinili. Glavna vzroka za to sta bila pomanjkanje slovenskih učiteljev in dejstvo, da so slovenski otroci že obvladali srbski jezik in tako niso več čutili potrebe po slovenski šoli. Maja 1946 so v Gudurici ustanovili kulturno-umetniško društvo "Sterija«. Njihova najbolj igrana igra je bila Hlapec Jernej in njegova pravica. Obstajala sta tudi mešani in 


\section{Lukić \\ »Drugega skoraj ne ostaja, ko ...}

moški pevski zbor. Za potrebe kulture so obnovili eno od stavb, v kateri so postavili oder in kulise. V kraju so odprli tudi čitalnico z okrog 300 knjigami, večinoma podarjenih iz Ljubljane. Leta 1946 so v Vršcu ustanovili kulturno-umetniško društvo »France Rozman«, ki je nastopalo po okoliških krajih. Istega leta so priredili javno trgatev. Društvo je delovalo do leta 1958. Do leta 1953 sta kulturni društvi delovali tudi v Veliki Gredi in Banatskem Plandištu, nato je delovanje društev zaradi množičnega odseljevanja Slovencev v Slovenijo zamrlo (Gaćeša 1984, 416).

Hitra adaptacija Slovencev na novo okolje se je kazala v mešanih porokah.Za Vršac, Veliko Gredo in Gudurico so podatki o poročenih Slovencih in Slovenkah naslednji: Slovenci so se najraje poročali s Srbkinjami (18 primerov), s Slovenkami (15), manj z Madžarkami, Hrvaticami. Slovenke so temu več ali manj sledile: poročene s Srbom (27), s Slovencem (12), z Madžarom (7), s Črnogorcem (3), po dve z Romunom in s Hrvatom, po ena z Makedoncem, Nemcem in Albancem. Največ porok $(45,9 \%)$ je bilo s Srbi in med samimi Slovenci (27,5 \%), s preostalimi narodi pa precej manj. Največ so se poročale Slovenke, ki so tako ostale v Banatu, moški pa so odhajali v Slovenijo. Zato so Slovenke, ki se niso poročale s Slovenci, ostajale v Banatu. Postale so del moževe družine in se niso več dojemale kot slovenske kolonistke (Pak 1963, 417).

Prav tako je zanimiva poklicna struktura kolonistov. V Gudurici so se znašli kmetje, poljski delavci, vrtnarji, delavci, po dva sodarja, čevljarja, kolarja in rudarja ter po en uslužbenec, zidar, kovač, lesni manipulant, mesar, mizar, mehanik (Pak 1963, 292). V Vršcu in okolici so se naselili kmečki kolonisti, ki so prihajali predvsem iz revnih viničarskih družin iz Slovenskih goric (Zupančič 2001, 292). Naseljevali so se tudi delavci, uslužbenci, obrtniki, dva zidarja in po en krojač, bolničarka, mizar, brivec, železničar, učitelj, trgovski pomočnik in gostilničar. Dobiti zaposlitev $v$ Vršcu je bila izjemno težka naloga, zato so se obrnili na okoliške kraje, kjer so se pretežno zaposlovali v zadrugi in na državnem posestvu. Precej pa jih je tudi po končani osemletki odšlo v Slovenijo (Pak 1963, 292).

Do leta 1947 se je zemljiščni fond, namenjen kolonizaciji, ter fond hiš za nastanitev povsem izčrpal, tako je tudi število zainteresiranih oseb padlo na minimum. Komisija za agrarno reformo in kolonizacijo pri vladi FLRJ se je 22. 6. 1947 odločila, da se kolonizacija ustavi. Konec leta 1947 govorimo o formalnopravnem zaključku kolonizacije Vojvodine. Nadaljnji obstoj organov, ki so kolonizacijo izvajali, je postal nesmiseln. Tako je bila 24. 4. 1948 ukinjena Komisija za agrarno reformo in kolonizacijo pri Vladi FLRJ, 20. 5. 1948 pa še Glavna komisija za naseljevanje borcev $\vee$ Vojvodini (Beljanski 1986, 3). 


\section{Povratništvo ali spontano odseljevanje iz Vojvodine}

Pogodbe o kolonizaciji so kolonistom prepovedale prodajo zemlje in hiše ali dajanje $v$ zakup, darovanje, deljenje in podobno, petnajst do dvajset let po prejemu. Zemlja kolonistov, ki so pred tem rokom odšli, je pripadla zadrugi, hišo pa je prevzela občina, zato je dosti kolonistov ostalo v Banatu do preteka roka. Vseeno so bili primeri, da so se vsi, razen stare matere ali očeta, vrnili v Slovenijo. Stari starši so ostali v Banatu, obdržali zemljo in jo pozneje po petnajstih do dvajsetih letih prodali in se $s$ tem prihodkom vrnili v Slovenijo. Primeri povratništva so se zgodili že takoj po končani kolonizaciji. Podatki o kraju in času odhoda so skopi, saj se večina ni odjavila, predvsem pa ne v prvih letih po kolonizaciji. Prav tako je nemogoče določiti število odseljenih, saj so ponekod odhajali posamezno, drugod $v$ večjem številu ali pa s celo družino (Pak 1963, 417, 422).

Do marca leta 1948 se je vrnilo 9,3 \% gospodinjstev in $9 \%$ vseh zunanjih kolonistov. Med vsemi republikami je bila Slovenija vodilna po odstotku kolonistov povratnikov: 31,3\%. Pri kolonistih iz okrajev Kočevje, Lendava, Mozirje je bilo povratništvo celo 50-odstotno. Nanj je vplivalo precej dejavnikov, kot so ekonomska razvitost kraja odselitve in kraja priselitve, oddaljenost, drugačno naravno okolje, nezmožnost prilagoditve ... Nekateri so ob povratku pričakovali boljše razmere doma, a jih niso našli. Povratništvo, ali obdobje spontanega odseljevanja, kot mu lahko pravimo, je trajalo precej dlje kot faza organiziranega priseljevanja. Nekaj časa je bil to prevladujoč tip migracij v Vojvodini (Đurđev 1995).

Iz južnobanatskih naselij Velika Greda, Banatsko Plandište in Dužine se je po podatkih Paka (1963) vrnilo največ slovenskih kolonistov. To območje je namreč težavno za aklimatizacijo, saj gre za obširna ravninska območja z bolj celinskim podnebjem, kar pomeni, da so bila poletja vroča, zrak suh in vroč, po mesec ali več ni bilo dežja, pozimi pa je pihala košava. Proces vračanja se je lahko začel kmalu po prihodu v Vojvodino ali po nekaj mesecih ali letih. Prve dneve so se iz južnobanatskih naselij vračali domov Prekmurci, ki so se najtežje ustalili, saj so bili vajeni sezonskega odhajanja na delo. Zgodilo se je tudi, da so si posamezniki prišli ogledat kraj naselitve in spoznat razmere, nato pa odšli po svoje družine. Precej se jih iz Slovenije ni več vrnilo.

Tako je znan čas odhoda za 295 družin z 904 člani od leta 1945 do 1960. Največ se jih je odselilo leta 1946. Povratniki so kot kraj povratništva izbirali večja industrijska središča v Sloveniji: Ljubljano, Maribor, Celje, Koper in Jesenice, prav tako pa so se vrnili v domače kraje.Zaposlili so se kot nekvalificirani delavci na primer v Litostroju in drugih podjetjih v Sloveniji. Kar enajst družin se je leta 1947 in 1948 vrnilo $v$ Apače pri Radgoni, ki so bile tedaj eno od izpraznjenih agrarnih območij v Sloveniji (Pak 1963, 423). 


\section{Lukić \\ »Drugega skoraj ne ostaja, ko ...}

Zaradi industrije je bilo največ povratnikov v ljubljanski (180 oseb) in mariborski okraj (136 oseb). Kar polovica 'mariborskih' povratnikov je prišla posamezno. Povratništvo v prvotne kraje bivanja po letu 1950 je potekalo tako, da so kolonisti predhodno poslali enega člana družine, ki je uredil stvari, pripravil bivališče in priskrbel zaposlitev. Po številu sprejetih povratnikov so si sledili celjski, murskosoboški, koprski, kranjski, novomeški in trboveljski okraj. Najmanj se jih je vrnilo v kočevski ter goriški okraj (Pak 1963, 424-5).

Podatki o povratništvu po mnenju dr. Branislava Đurđeva (1995, 66) niso povsem verodostojni, saj verjetno niso zabeleženi vsi primeri kolonistov povratnikov. Lahko so se namreč vrnili posamezniki ali pa celotne družine. France Cevc $(2001,316)$ navaja, da se je do leta 1960 izselilo 295 družin z nekaj več kot 900 člani. V južnem Banatu naj bi v začetku leta 1960 tako živelo le še 182 slovenskih družin (Gaćeša 1984, 327) oziroma 22,2 \% vseh kolonistov, ki so prišli v južni Banat (Pak 1963, 417-8).

\section{Obdobje po kolonizaciji}

$\checkmark$ vseh teh obdobjih ne smemo pozabiti, da so se v vrtincu organiziranih in sporadičnih preseljevanj znašli tudi ljudje, ki so se selili, in se vedno bodo, iz povsem osebnih vzgibov. Zgodba Terezije Beznec, rojene leta 1921 v Bodoncih pri Murski Soboti, ki se je poročila s Štefanom Beznecem in preselila $v$ Vojvodino, je samo ena izmed mnogih, ki bo njunim potomcem in nam ostala kot pričevanje slovenskih izseljencev: »Poročila sva se leta 1948, kmalu po mojem prihodu v Novi Sad. V kratkem času mi je priznal, da se ne more več vrniti v Slovenijo. Imel je probleme $s$ sinusi in ga je $v$ Sloveniji na ostrem zraku pogosto bolela glava.Zdravniki so mu svetovali, da bo za njega najboljše, da živi v Vojvodini. Ker ni mogel živeti v Sloveniji in ker sem jaz želela živeti z njim, sem tu ostala« (Stojanović 2006, 10).

Tok priseljevanja v Vojvodino iz Slovenije je bil, v primerjavi z drugimi, med 'slabšimi', na kar sta dodatno vplivala procesa povratništva in druge migracije, ki sta prispevala, da se je med Vojvodino in Slovenijo postopoma oblikovala negativna migracijska bilanca (Đurđev 1995, 102).

Največ slovenskih priseljencev po letu 1946 je odšlo v Vršac. To niso bili kolonisti, temveč uslužbenci in kvalificirani delavci, ki so se zaposlovali v tamkajšnji industriji. V največ primerih so to bili posamezniki brez družin, ki so prišli h kakšni slovenski družini ali pa so iskali priložnost, da se vselijo v hišo kakšnega kolonista, ki se je vrnil v Slovenijo, ali pa so odkupovali obdelovalno zemljo od zadrug (Pak 1963, 402).

Spolna struktura vojvodinskega prebivalstva, rojenega v Sloveniji, pokaže, da je bilo leta 1948 priseljenih več moških kot žensk. Do naslednjega popisa se je delež izenačil, medtem ko je popis leta 1961 po- 
kazal, da je bilo več žensk kot moških. Leta 1948 je v Sloveniji opazna manjša stopnja maskulinitete, od tu pogostejše preseljevanje moških v Vojvodino. Zasuk v poznejših letih po mnenju Đurđeva $(1995,112)$ lahko pripišemo stopnji ekonomske emancipacije žensk v Sloveniji.

Po starostni strukturi so medrepubliške migracije $v$ Vojvodino zvabile mlajše Makedonce, Črnogorce in Srbe, rojene zunaj Srbije, medtem ko so bili starejši letniki Hrvati in Slovenci (Bukurov 1957, 53). Popis iz leta 1961 je zajel samo prebivalstvo, katerih mesto priseljevanja in starost sta bila znana. Za naseljence, rojene v Sloveniji, so na vzorcu 4825 poznanih starosti ugotovili srednjo starost 37,38 let (Đurđev 1995).

Za zaključek si še oglejmo število prebivalcev v Vojvodini, ki so se v povojnih popisih izjasnili kot Slovenci (Đurđev 1995, 139-40): leta 1948 0,44 \% celotnega prebivalstva Vojvodine (7223 oseb), leta 1953 0,35\% (6025 oseb), leta 1961 0,30 (5633 oseb), leta 1971 0,24 \% (4639 oseb) in leta 1981 0,17\% (3456 oseb). Padec naseljevanja slovenskega etničnega življa v Vojvodino je očiten od popisa do popisa. Ob dejstvu, da Slovenci v Vojvodino niso prihajali samo iz Slovenije, temveč tudi iz preostale Srbije, Kosova in Metohije, Makedonije, Črne gore, Hrvaške in Bosne in Hercegovine (izjema leto 1961), moramo upoštevati tudi, da se iz Vojvodine niso vračali nazaj samo v Slovenijo, temveč tudi v našteta območja (Đurđev 1995, 145).

Po zadnjem popisu prebivalstva Republike Srbije iz leta 2011 se je $v$ Vojvodini 1815 oseb po narodnosti opredelilo kot Slovenci, kar predstavlja 0,09 \% celotnega prebivalstva pokrajine (Gavrilović 2017). Slovenci v Vojvodini se danes medsebojno povezujejo v petih društvih: Društvo Slovencev »Kredarica « v Novem Sadu, Društvo Slovencev »Triglav« v Subotici, Društvo Slovencev »Planika« v Zrenjaninu, Društvo Slovencev »Kula« v Vršcu in Društvo Slovencev »Emona« v Rumi.

Literatura

Beljanski, Milenko. 1986. 40 godina posle agrarne reforme i kolonizacije. Sombor : Prosveta.

Bukurov, Branislav. 1957. Poreklo stanovništva Vojvodine. Novi Sad : Matica srpska.

Cevc, France. 2001. »Slovenci v AP Vojvodini (ZR Jugoslavija).« V Slovensko izseljenstvo, Zbornik ob 50-letnici Slovenske izseljenske matice, ur. Milica Trebše Štolfa in Matjaž Klemenčič, 313-318. Ljubljana : Združenje Slovenska izseljenska matica.

Cvijić, Jovan. 1987. Balkansko poluostrvo. Sabrana dela, knjiga 2. Beograd : SANU.

Čalar, M. 22. 3. 1946. Kolonisti Elemira vredno rade svoju zemlju. Kolonista nedeljni prilog Slobodne Vojvodine I (5) : 1.

Domonji, Pavel. 2000. V Nacionalne zajednice i etničke grupe u Vojvodini. Osnovni podaci, ur. Jovan Zelenović, 7-22. Novi Sad : Pokrajinski sekretarijat za ostvarivanje prava nacionalnih manjina, upravu i propise. 


\section{Lukić}

»Drugega skoraj ne ostaja, ko ...

Đurđev, Branislav S. 1995. Posleratno naseljavanje Vojvodine. Metodi i rezultati demografske analize naseljavanja Vojvodine u periodu 1945-1981. Novi Sad : Matica srpska.

Ferenc, Tone. 1968. Nacistična raznarodovalna politika $v$ Sloveniji v letih 1941 1945. Maribor : Obzorja.

Filipović, Milenko S. 1958. Proučavanje naseljavanja Vojvodine. Novi Sad : Matica srpska.

Gaćeša, Nikola L. 1968. Agrarna reforma i kolonizacija u Bačkoj 1918-1941. Novi Sad : Matica srpska.

Gaćeša, Nikola L. 1972. Agrarna reforma i kolonizacija u Banatu 1919-1941. Novi Sad : Matica srpska.

Gaćeša, Nikola L. 1975. Agrarna reforma i kolonizacija u Sremu 1919-1941. Novi Sad: Institut za izučavanje istorije Vojvodine.

Gaćeša, Nikola L. 1984. Agrarna reforma i kolonizacija u Jugoslaviji 1945-48. Novi Sad : Matica srpska.

Gaćeša, Nikola L. 1995. Radovi iz agrarne istorije i demografije. Novi Sad : Matica srpska.

Gavrilović, Dušan (ur.) 2017. Statistički godišnjak Republike Srbije 2017. Beograd : Republički zavod za statistiku.

Gvozdenac, Dragan. 1. 2. 1946. Druga etapa u izvodjenju agrarne reforme u Vojvodini - nadeljivanje zemlje. Slobodna Vojvodina V (390) : 3.

Iskruljev, Toša. 1925. O Vojvodini i njenoj kolonizaciji. Novi Sad : Zastava.

Kržišnik-Bukić, Vera.1992. O Slovencih na območju Jugoslavije izven Slovenije po popisih prebivalstva 1921-1991. Razprave in gradivo : revija za narodnostna vprašanja 26-27: 172-199.

Küzmič, Mihael. 2001. "Slovenski protestanti in izseljenstvo.« V Slovensko izseljenstvo, Zbornik ob 50-letnici Slovenske izseljenske matice, ur. Milica Trebše Štolfa in Matjaž Klemenčič, 149-158. Ljubljana : Združenje Slovenska izseljenska matica.

Lukšin Hacin, Marina. 1995. Ko tujina postane dom. Ljubljana : Znanstveno in publicistično središče.

Neznan avtor, 25. 8. 1945. Zakon o agrarnoj reformi i kolonizaciji. Slobodna Vojvodina I (185) : 3-4.

Neznan avtor, 26. 1. 1946a. Rudari Vrdnika su pobedili u takmičenju rudara Srbije. Slobodna Vojvodina V (385) : 1.

Neznan avtor, 16. 4. 1946b. Sprovodjenje agrarne reforme u Vojvodini. Širom Banata i Bačke održavaju se zborovi za podelu eksproprisane zemlje. Slobodna Vojvodina V (455) : 1.

Pak, Mirko. 1963. Kolonizacija Slovencev v Banatu. Geografski zbornik 8: 395-428.

Popović, Dušan. 1925. Vojvodina. Prilozi proučavanju naše zemlje i našeg naroda. Beograd : Rodoljub.

Roš, Fran. 1967. Slovenski izgnanci v Srbiji 1941-1945. Maribor : Obzorja. 
S.J., 26. 7.1865. O preseljevanju Slovencev v tuje dežele. Kmetijske in rokodelske novice: 237.

Stipetić, Vladimir. 1954. Agrarna reforma i kolonizacija u FNRJ godine 1945.-1948. Zagreb : Jugoslavenska akademija znanosti i umjetnosti.

Stojanović, Srdjan. 2006. Sestavki učencev dopolnilnega pouka slovenščine: Moja babica Terezija Beznec. Kredarica : bilten društva Slovencevv Novem Sadu VI (21) : 10.

Trunk, Jurij Matej. 1912. Amerika in Amerikanci. Celovec : Samozaložba.

Zupančič, Jernej. 2001. "Slovensko izseljenstvo v Evropi po drugi svetovni vojni.« V Slovensko izseljenstvo,Zbornik ob 50-letnici Slovenske izseljenske matice. ur. Milica Trebše Štolfa in Matjaž Klemenčič, 291-299. Ljubljana :Združenje Slovenska izseljenska matica.

\author{
Dijana Lukić \\ Univerzitet u Ljubljani \\ Filozofski fakultet \\ Slovenija \\ dijana.lukic@gmail.com
}

\title{
„SKORO DA NEMA DRUGE, NEGO NAPUSTITI MILU DOMOVINU I TRAŽITI DRUGDE DOM“ILI KRATAK PREGLED MIGRACIONIH TOKOVA SLOVENACA U VOJVODINU
}

Migracije su bile i zauvek ostaju neizbežan deo ličnog i kolektivnog života. U ljudskoj je prirodi težnja za migracijom, bilo kao deo svesnog ili nesvesnog procesa, posledica planiranih ili neplaniranih politika, socioekonomskog razvoja ili drugih karakteristika sredine, bilo prosto kao rezultat određenih ličnih potreba i želja pojedinca. Vojvodina je oduvek bila privlačna teritorija za naseljavanje i prožimanje različitih etničkih grupa, i deo tog demografskog bogatstva, koje se danas pokazuje u obliku multipripadnosti i transnacionalne identifikacije, bili su i jesu takođe Slovenci. Ovaj tekst predstavlja deo obimnije istorijsko-etnološke obrade Slovenaca u Vojvodini, koja je nastala na osnovu autorkinog terenskog rada u Novom Sadu, u periodu od oktobra 2007. do februara 2008. godine, i bila je u celini objavljena u diplomskom radu „Slovenci v Vojvodini: društvo Slovencev 'Kredarica' v Novem Sadu“ (Odeljenje za etnologiju i kulturnu antropologiju Filozofskog fakulteta Univerziteta u Ljubljani, 2009). Autorka prikazuje istoriju naseljavanja Slovenaca u Vojvodini od kraja 19. veka do 1981. godine, stavljajući poseban akcenat na dva uzajamna procesa - agrarnu reformu i kolonizaciju, koji su zaslužni za slovenački udeo među vojvođanskim stanovništvom, pri čemu naročito ističe fragmente etnoloških svedočanstava iz privatnih priča pojedinaca, koje otkrivaju motive i uzroke emigracije iz zavičaja.

Ključne reči: migracije, iseljenici, kolonizacija, agrarna reforma, Slovenci u Vojvodini 


\section{Lukić}

»Drugega skoraj ne ostaja, ko ...

Dijana Lukić

University of Ljubljana

Faculty of Philosophy

Slovenia

dijana.lukic@gmail.com

\section{“THERE IS ALMOST NO OTHER CHOICE BUT TO LEAVE THE BELOVED FATHERLAND AND SEEK FOR ANOTHER HOMELAND": A BRIEF OVERVIEW OF THE INFLUX OF SLOVENIAN IMMIGRANTS IN VOJVODINA}

Migrations have been and will forever remain an inevitable part of personal and collective life. The desire for migration is rooted in human nature - be it part of a conscious or unconscious process, a consequence of planned or unplanned policies, socio-economic development or other characteristics of the environment, or rather a result of some personal needs and desires of an individual. Vojvodina has always been an attractive territory for settlement and interweaving of various ethnic groups, and Slovenians have also been part of this demographic richness, which is today reflected in multiple ethnic affiliations and transnational identification. This paper is part of a more extensive historical and ethnological study on Slovenians in Vojvodina, based on the author's field research conducted in Novi Sad, between October 2007 and February 2008. The complete study was presented in the graduation thesis Slovenians in Vojvodina: Slovenians' Association Kredarica in Novi Sad (Department of Ethnology and Cultural Anthropology, Faculty of Philosophy, University of Ljubljana, 2009). The author traces the history of the settlement of Slovenians in Vojvodina from the late $19^{\text {th }}$ century until 1981, putting special emphasis on two inter-related processes - the agrarian reform and colonization, which largely explain the share of Slovenians in the population of Vojvodina. In this context, special attention is paid to the fragments of ethnological testimonies extracted from private stories of individuals which reveal the motives and causes of emigration from their homeland.

Keywords: migrations, emigrants, colonization, agrarian reform, Slovenians in Vojvodina 